JP3I (Jurnal Pengukuran Psikologi dan Pendidikan Indonesia), 7(I), 2018, 8-14

D0l: http://dx.doi.org/I0.15408/p3i.v7il.12103

http://journal.uinjkt.ac.id/index.php/jp3i

\title{
UJI VALIDITAS KONSTRUK PADA INSTRUMEN RYFF'S PSYCHOLOGICAL WELL-BEING SCALE DENGAN METODE CONFIRMATORY FACTOR ANALYSIS (CFA)
}

\author{
Merlyna Revelia \\ UIN Syarif Hidayatullah Jakarta \\ reveliamerlyn@gmail.com
}

\begin{abstract}
Psychological well-being is a condition that enables a person to release his full potential in undergoing a life-long existential challenge. Such an individual will focus on lifelong self-development or in other words, he is a lifelong learner. According to Ryff and Keyes (1995), psychological well-being includes six dimensions, namely self-acceptance, positive relations with others, autonomy, purpose in life, personal growth, and environmental mastery. This study aims to examine the construct validity of the instrument. The data in this study were obtained from santri boarding schools that were settled in Islamic boarding schools totaling 159 people. The method used to test it is confirmatory factor analysis (CFA) using LISREL 8.70 software. The results of this study show that all items totaling 43 items are unidimensional. This means that all items only measure one factor so that the one factor model is theorized by acceptable.
\end{abstract}

Keywords : construct validity test; psychological well-being; big five personality; adversity quotient; confirmatory factor analysis (CFA)

\begin{abstract}
Abstrak
Psychological well-being merupakan kondisi mampunya seseorang mengeluarkan potensi penuh yang dimiliki dalam menjalani tantangan eksistensial kehidupan yang berlangsung lama. Individu demikian akan memfokuskan untuk pengembangan diri sepanjang umur atau dengan kata lain, ia merupakan pembelajar seumur hidup. Menurut Ryff dan Keyes (1995), psychological well-being meliputi enam dimensi, yaitu self-acceptance, positive relation with others, autonomy, purpose in life, personal growth, dan environmental mastery. Penelitian ini bertujuan untuk menguji validitas konstruk instrumen tersebut. Data dalam penelitian ini diperoleh dari santri pondok pesantren yang sedang menetap di pondok pesantren berjumlah 159 orang. Metode yang digunakan untuk mengujinya adalah confirmatory factor analysis (CFA) menggunakan software LISREL 8.70. Hasil dari penelitian ini menunjukkan bawa seluruh item yang berjumlah 43 item bersifat unidimensional. Artinya seluruh item hanya mengukur satu faktor saja sehingga model satu faktor yang diteorikan oleh dapat diterima.

Kata Kunci: uji validitas konstruk; psychological well-being; big five personality; adversity quotient; confirmatory factor analysis (CFA)
\end{abstract}




\section{Pendahuluan}

Psychological well-being merupakan konstruk psikologis di mana banyak ahli teori mengusahakan untuk mendapatkan definisi yang tepat. Pada awalnya, psychological well-being sering kali didefinisikan dengan kebahagiaan, namun kebahagiaan itu sendiri lebih tepat untuk mendeskripsikan subjective well-being, bukan sebagai psychological well-being.

Dalam mendefinisikan psychological well-being, Aristoteles (dalam Ryff, I989) membedakannya menjadi dua konsep dasar, yaitu hedonic dan eudemonic. Hedonic berkaitan dengan kesenangan atau tidak adanya perasaan-perasaan negatif di mana dikaitkan dengan subjective well-being, sedangkan eudemonic berkaitan dengan kesadaran seseorang terhadap potensi sebenarnya di mana dikaitkan dengan psychological well-being.

Huppert (2009) menjelaskan bahwa psychological well-being atau yang dikenal juga sebagai objective wellbeing ataupun sustainable well-being merupakan kombinasi dari perasaan positif dan berfungsinya individu secara efektif. Psychological well-being disebut sebagai objective well-being dikarenakan terdapat dimensidimensi yang dinilai lebih objektif dibandingkan dimensi subjective well-being. Disebut sebagai sustainable well-being dikarenakan psychological well-being dinilai berlangsung lebih lama (memiliki efek jangka panjang) dibandingkan dengan subjective well-being yang dinilai hanya jangka pendek, walaupun secara umum psychological well-being dan subjective well-being sama-sama memiliki arti kebahagiaan (happiness).

Untuk membedakan antara psychological well-being dengan subjective well-being (yang bersifat hedonistik), Carol Ryff (dalam Vasquez, Hervas, Rahona, \& Gomez, 2009) berusaha mengatasi keterbatasan ini dan mendefinisikan psychological well-being sebagai berkembangnya potensi sejati individu, sehingga psychological well-being bukanlah motivasi utama seseorang melainkan hasil dari baiknya kehidupan seseorang. Lebih jauh, Carol Ryff (Keyes et al., 2002) merumuskan beberapa dimensi psychological wellbeing, sehingga psychological well-being didefinisikan sebagai kondisi atas kemampuan seseorang terhadap tantangan eksistensial kehidupan di mana merujuk pada enam dimensi, antara lain:

I. Self-acceptance (penerimaan diri) adalah penerimaan diri dan penerimaan kehidupan lampau seseorang sehingga bisa dikarakteristikan dengan self-actualization, optimal functioning (fungsi optimal individu), dan maturity (kedewasaan).

2. Positive relations with others (hubungan positif dengan orang lain), yaitu dimesi yang menitikberatkan pada pentingnya kehangatan, rasa percaya dalam hubungan interpersonal.

3. Autonomy (otonomi) merupakan fungsi di mana individu mampu memerintahkan untuk dirinya sendiri, seperti mengambil keputusan sendiri

4. Environmental mastery (penguasaan lingkungan) adalah kemampuan individu untuk memilih atau menciptakan lingkungan yang cocok untuk dirinya, sehingga suksesnya pertambahan usia menitikberatkan pada luasnya individu dalam memanfaatkan kesempatan-kesempatan di lingkungannya.

5. Purpose in life (tujuan hidup), yaitu rasa terhadap tujuan dan makna hidup di mana dimensi ini menjelaskan bahwa adanya tujuan hidup yang bervariasi meliputi bersikap produktif, kreatif, dan tercapainya penyatuan emosional di kehidupan kemudian.

6. Personal growth (pertumbuhan pribadi) merupakan kontinuitas pertumbuhan dan menghadapi tantangan atau tugas baru di periode kehidupan yang berbeda.

\section{Deskripsi Mengenai Instrumen}

Ryff (1989) telah mengukur psychological well-being melalui dimensi-dimensi psychological well-being yang disebut dengan Ryffs Psychological Well-Being Scale, terdiri dari enam dimensi yang membentuk psychological well-being dan keberadaannya saling memiliki keterkaitan, yaitu self-acceptance, autonomy, 
environmental mastery, purpose in life, positive relations with others dan personal growth. Instrumen ini terdiri atas 43 item di mana terdapat 7 item autonomy, 8 item environmental mastery, 7 item personal growth, 7 item self-acceptance, dan 7 item purpose in life, dan 7 item positive relations with others. Contoh item Ryffs Psychological Well-Being Scale yang telah direvisi, yaitu sebagai berikut:

Tabel I. Ryffs s Pychological Well-Being Scale

\begin{tabular}{|c|c|}
\hline No. & Pernyataan \\
\hline I. & Aku tidak takut menyatakan pendapatku bahkan ketika bertentangan dengan pendapat banyak orang. \\
\hline 2. & Umumnya, aku merasa berwenang di situasi di mana aku berada. \\
\hline 3. & Aku tidak tertarik dalam kegiatan yang memperluas pengetahuanku. \\
\hline 4. & Banyak orang melihatku sebagai orang yang penyayang dan penuh kasih. \\
\hline 5. & Aku hidup saat ini dan tidak memikirkan hari esok. \\
\hline 6. & Ketika aku melihat perjalanan hidupku, aku puas dengan apa yang terjadi. \\
\hline 7. & Keputusanku biasanya tidak dipengaruhi oleh apa yang dilakukan orang lain. \\
\hline 8. & Tuntutan kehidupan setiap hari sering membuatku lesu. \\
\hline 9. & $\begin{array}{l}\text { Aku pikir merupakan hal yang penting untuk memiliki pengalaman baru yang menantang cara } \\
\text { berpikirku maupun cara berpikir orang lain. }\end{array}$ \\
\hline IO. & Memelihara hubungan dekat merupakan hal yang sulit dan mengecewakan. \\
\hline II. & Aku memiliki arah dan tujuan hidup. \\
\hline $\mathrm{I} 2$. & Pada umumnya, aku percaya diri dan merasa positif tentang diriku. \\
\hline $\mathrm{I} 3$. & Aku cenderung cemas apa yang orang lain pikirkan tentangku. \\
\hline $\mathrm{I} 4$. & Aku tidak begitu cocok dengan orang lain dan lingkungan di sekitarku. \\
\hline I5. & Aku pikir aku belum meningkatkan kemampuanku. \\
\hline I6. & Aku sering merasa sepi karena hanya memiliki beberapa teman dekat untuk berbagi. \\
\hline I7. & Aktivitas harianku terlihat sepele dan tidak penting bagiku. \\
\hline I8. & $\begin{array}{l}\text { Aku merasa orang lain yang ku tahu memiliki banyak kehidupan yang mereka inginkan dibandingkan } \\
\text { denganku. }\end{array}$ \\
\hline 19. & Aku cenderung dipengaruhi oleh orang yang memiliki pendapat kuat. \\
\hline 20. & Aku cukup baik dalam mengatur banyak kewajiban di kehidupan sehari-hari. \\
\hline $2 \mathrm{I}$. & Aku merasa bahwa aku banyak berkembang dari waktu ke waktu. \\
\hline 22. & $\begin{array}{l}\text { Aku menikmati percakapan perseorangan ataupun percakapan ramai-ramai dengan anggota keluargaku } \\
\text { ataupun dengan temanku. }\end{array}$ \\
\hline 23. & Aku tidak merasa baik dari apa yang sedang aku capai di dalam hidup. \\
\hline 24. & Aku menyukai banyak hal tentang kepribadianku. \\
\hline 25. & Aku percaya diri dengan pendapatku meskipun bertentangan dengan pendapat umum. \\
\hline 26. & Aku sering merasa kewalahan atas kewajibanku. \\
\hline 27. & $\begin{array}{l}\text { Aku tidak menikmati berada di situasi baru yang mengharuskanku mengubah cara-cara yang biasa aku } \\
\text { lakukan. }\end{array}$ \\
\hline
\end{tabular}




\begin{tabular}{|c|c|}
\hline 28. & $\begin{array}{l}\text { Orang-orang menggambarkanku sebagai orang yang senang memberi, bersedia berbagi waktu dengan } \\
\text { orang lain. }\end{array}$ \\
\hline 29. & Aku senang membuat rencana untuk masa depan dan bekerja untuk membuatnya menjadi kenyataan. \\
\hline 30. & Di banyak hal, aku kecewa dengan pencapaian hidupku. \\
\hline $3 \mathrm{I}$. & Sulit bagiku mengutarakan pendapatku tentang hal yang diperdebatkan. \\
\hline 32. & Aku kesulitan mengatur kehidupanku dengan cara yang memuaskan. \\
\hline 33. & Bagiku, kehidupan merupakan proses belajar, berubah, dan berkembang secara terus-menerus. \\
\hline 34. & Aku tidak mengalami kehangatan dan mempercayai hubungan dengan orang lain. \\
\hline 35. & Beberapa orang menjalani hidup tanpa tujuan, namun aku bukanlah salah satu dari mereka. \\
\hline 36. & $\begin{array}{l}\text { Sikapku terhadap diri sendiri mungkin tidak sepositif kebanyakan orang yang merasa tentang diri } \\
\text { mereka. }\end{array}$ \\
\hline 37. & $\begin{array}{l}\text { Aku menilai diriku dengan apa yang aku anggap penting, bukan dengan apa yang orang lain anggap } \\
\text { penting. }\end{array}$ \\
\hline 38. & Aku mampu membangun lingkungan yang nyaman. \\
\hline 39. & Aku menyerah untuk melakukan perbaikan besar atau mengubah kehidupanku beberapa waktu lalu. \\
\hline 40. & Aku tahu aku bisa mempercayai teman-temanku, dan mereka pun tahu mereka bisa mempercayaiku. \\
\hline $4 \mathrm{I}$. & Terkadang saya merasa saya telah melakukan semua di kehidupanku. \\
\hline 42. & $\begin{array}{l}\text { Ketika aku membandingkan diriku dengan teman dan kenalanku, hal itu membuatku merasa lebih baik } \\
\text { mengenai keadaanku. }\end{array}$ \\
\hline 43. & embangun gaya hidup untuk diriku di mana sesuai dengan yang aku sukai. \\
\hline
\end{tabular}

Ryffs Psychological Well-Being Scale memiliki empat kategori jawaban yaitu: "Sangat Sesuai” (SS), "Sesuai” (S), "Tidak Sesuai” (TS), "Sangat Tidak Sesuai” (STS). Untuk penyekorannya, hanya memberikan penilaian tertinggi pada pernyataan "Sangat Sesuai" (SS) dan terendah pada pilihan "Sangat Tidak Sesuai" (STS) untuk pernyataan favorable. Untuk penyekoran item unfavorable, penilaian tertinggi pada pernyataan "Sangat Tidak Sesuai" (STS) dan terendah pada pilihan "Sangat Sesuai” (SS). Skor-skor tersebut kemudian dihitung, dengan proporsi item yang yang bersifat favorable dengan ketentuan sebagai berikut: $\mathrm{SS}=4, \mathrm{~S}=3$, $\mathrm{TS}=2$, STS $=\mathrm{I}$. Untuk item yang bersifat unfavorable dihitung dengan ketentuan sebagai berikut: $\mathrm{SS}=\mathrm{I}, \mathrm{S}$ $=2, \mathrm{TS}=3$, STS $=4$.

\section{Metode}

Untuk menguji validitas konstruk instrumen pengukuran Ryffs Psychological Well-Being Scale ini menggunakan pendekatan analisis faktor berupa confirmatory factor analysis (CFA). Pengujian analisis CFA seperti ini dilakukan dengan bantuan software LISREL 8.70.

Adapun logika dari CFA (Umar, 20I I) adalah sebagai berikut:

I. Bahwa ada sebuah konsep atau trait berupa kemampuan yang didefinisikan secara operasional sehingga dapat disusun pertanyaan atau pernyataan untuk mengukurnya. Kemampuan ini disebut faktor, sedangkan pengukuran terhadap faktor ini dilakukan melalui analisis terhadap respon atas item itemnya. 
2. Diteorikan setiap item hanya mengukur satu faktor saja, begitupun juga tiap subtes hanya mengukur satu faktor juga. Artinya baik item maupun subtes bersifat unidimensional.

3. Dengan data yang tersedia dapat digunakan untuk mengestimasi matriks korelasi antar item yang seharusnya diperoleh jika memang unidimensional. Matriks korelasi ini disebut sigma $\left(\sum\right)$, kemudian dibandingkan dengan matriks dari data empiris, yang disebut matriks S. Jika teori tersebut benar (unidemensional) maka tentunya tidak ada perbedaan antara matriks $\sum$ - matriks $S$ atau bisa juga dinyatakan dengan $\sum-\mathrm{S}=0$.

4. Pernyataan tersebut dijadikan hipotesis nihil yang kemudian diuji dengan chi square. Jika hasil chi square tidak signifikan $(\mathrm{p}>0.05)$, maka hipotesis nihil tersebut "tidak ditolak". Artinya teori unidimensionalitas tersebut dapat diterima bahwa item ataupun sub tes instrumen hanya mengukur satu faktor saja. Sedangkan, jika nilai Chi-Square signifikan $(p<0.05)$, artinya bahwa item tersebut mengukur lebih dari satu faktor atau bersifat multidimensional. Maka perlu dilakukan modifikasi terhadap model pengukuran.

5. Adapun dalam memodifikasi model pengukuran dilakukan dengan cara membebaskan parameter berupa korelasi kesalahan pengukuran. Hal ini terjadi ketika suatu item mengukur selain faktor yang hendak diukur. Setelah beberapa kesalahan pengukuran dibebaskan untuk saling berkorelasi, maka akan diperoleh model yang fit, maka model terakhir inilah yang akan digunakan pada langkah selanjutnya.

6. Jika model fit, maka langkah selanjutnya menguji apakah item signifikan atau tidak mengukur apa yang hendak diukur, dengan yang hendak di ukur, dengan menggunakan t-test. Jika hasil t-test tidak signifikan $(\mathrm{t}<\mathrm{I}, 96)$ maka item tersebut tidak signifikan dalam mengukur apa yang hendak diukur, bila perlu item yang demikian didrop dan sebaliknya.

7. Selain itu, apabila dari hasil CFA terdapat item yang koefisien muatan faktornya negatif, maka item tersebut juga harus didrop. Sebab hal ini tidak sesuai dengan sifat item, yang bersifat positif (favorable).

8. Kemudian, apabila terdapat korelasi parsial atau kesalahan pengukuran item terlalu banyak berkorelasi dengan kesalahan pengukuran lainnya, maka item tersebut akan didrop. Sebab, item yang demikian selain mengukur apa yang hendak diukur, ia juga mengukur hal lain (multidimensi). Adapun asumsi didrop atau tidaknya item adalah jika tidak terdapat lebih dari tiga korelsi parsial atau kesalahan pengukuran yang berkorelasi dengan item lainnya.

9. Terakhir, setelah dilakukan langkah-langkah seperti yang telah disebutkan di atas. Dan mendapatkan item dengan muatan faktor signifikan $(t>1.96)$ dan positif. Maka, selanjutnya item-item yang signifikan ( $>$ I.96) dan positif tersebut diolah untuk nantinya didapatkan faktor skornya.

\section{Hasil}

Peneliti menguji apakah 43 item yang ada bersifat unidimensional yang artinya item tersebut hanya mengukur psychological well-being. Dari hasil analisis CFA yang dilakukan dengan model satu faktor, ternyata tidak fit, dengan $C h i-S q u a r e=2377.04, \mathrm{df}=860, \mathrm{P}$-value $=0.00000, \mathrm{RMSEA}=0.106$. Oleh sebab itu, peneliti melakukan modifikasi terhadap model, di mana kesalahan pengukuran pada beberapa item dibebaskan berkorelasi satu sama lainnya, maka diperoleh model fit dengan Chi-Square=763.9I, df $=702$, Pvalue $=0.0522 \mathrm{I}, \mathrm{RMSEA}=0.024$. Berdasarkan hal tersebut, diketahui bahwa nilai Chi-Square menghasilkan Pvalue $>0.05$ (tidak signifikan), yang artinya model dengan satu faktor dapat diterima, bahwa seluruh item mengukur satu faktor saja yaitu :psychological well-being.

Kemudian melihat apakah signifikan item tersebut mengukur faktor yang hendak diukur. Sekaligus menentukan apakah item tersebut perlu didrop atau tidak. Dalam hal ini yang diuji adalah hipotesis nihil tentang koefisien muatan faktor dari item. Pengujiannya dilakukan dengan melihat nilai t bagi setiap koefisien muatan faktor, seperti pada tabel berikut. 
JP3I (Jurnal Pengukuran Psikologi dan Pendidikan Indonesia), 7(1), 2018

Tabel 2. Muatan Faktor Item Psychological Well-Being

\begin{tabular}{|c|c|c|c|c|}
\hline No & Koefisien & Standar Error & Nilai t & Signifikan \\
\hline I & 0.16 & 0.08 & 1.96 & $\mathrm{~V}$ \\
\hline 2 & 0.20 & 0.08 & 2.52 & $\mathrm{~V}$ \\
\hline 3 & -0.14 & 0.09 & -1.65 & $\mathrm{X}$ \\
\hline 4 & -0.05 & 0.08 & -0.58 & $\mathrm{X}$ \\
\hline 5 & 0.40 & 0.08 & $5.0 \mathrm{I}$ & $\mathrm{V}$ \\
\hline 6 & 0.22 & 0.08 & 2.64 & $\mathrm{~V}$ \\
\hline 7 & 0.35 & 0.08 & 4.32 & $\mathrm{~V}$ \\
\hline 8 & 0.17 & 0.08 & 2.03 & $\mathrm{~V}$ \\
\hline 9 & 0.38 & 0.08 & 4.57 & $\mathrm{~V}$ \\
\hline 10 & 0.49 & 0.08 & 6.17 & $\mathrm{~V}$ \\
\hline II & $0.5 \mathrm{I}$ & 0.08 & 6.47 & $\mathrm{~V}$ \\
\hline $\mathrm{I} 2$ & $0.0 \mathrm{I}$ & 0.08 & $0 . \mathrm{II}$ & $\mathrm{X}$ \\
\hline $\mathrm{I} 3$ & -0.03 & 0.09 & -0.37 & $\mathrm{X}$ \\
\hline $\mathrm{I} 4$ & 0.52 & 0.08 & 6.56 & $\mathrm{~V}$ \\
\hline 15 & $0.5 \mathrm{I}$ & 0.08 & 6.72 & $\mathrm{~V}$ \\
\hline 16 & 0.40 & 0.08 & 5.08 & $\mathrm{~V}$ \\
\hline 17 & 0.44 & 0.08 & 5.58 & $\mathrm{~V}$ \\
\hline 18 & 0.27 & 0.09 & 3.08 & $\mathrm{~V}$ \\
\hline 19 & 0.67 & 0.07 & 8.97 & $\mathrm{~V}$ \\
\hline 20 & 0.26 & 0.08 & 3.18 & $\mathrm{~V}$ \\
\hline $2 \mathrm{I}$ & 0.76 & 0.07 & $\mathrm{I} 0.2 \mathrm{I}$ & $\mathrm{V}$ \\
\hline 22 & $0.5 \mathrm{I}$ & 0.08 & 6.40 & $\mathrm{~V}$ \\
\hline 23 & 0.44 & 0.08 & 5.49 & $\mathrm{~V}$ \\
\hline 24 & 0.24 & 0.08 & 2.87 & $\mathrm{~V}$ \\
\hline 25 & 0.30 & 0.08 & 3.52 & $\mathrm{~V}$ \\
\hline 26 & 0.59 & 0.08 & 7.60 & $\mathrm{~V}$ \\
\hline 27 & $0.6 \mathrm{I}$ & 0.08 & 8.06 & $\mathrm{~V}$ \\
\hline 28 & 0.34 & 0.08 & 4.28 & $\mathrm{~V}$ \\
\hline 29 & 0.63 & 0.08 & 8.20 & $\mathrm{~V}$ \\
\hline 30 & 0.24 & 0.08 & 2.92 & $\mathrm{~V}$ \\
\hline $3 I$ & 0.70 & 0.08 & 9.13 & $\mathrm{~V}$ \\
\hline 32 & 0.45 & 0.08 & 5.79 & $\mathrm{~V}$ \\
\hline 33 & 0.17 & 0.08 & $2.0 \mathrm{I}$ & $\mathrm{V}$ \\
\hline 34 & 0.59 & 0.08 & 7.59 & $\mathrm{~V}$ \\
\hline 35 & 0.60 & 0.08 & 7.48 & $\mathrm{~V}$ \\
\hline 36 & -0.07 & 0.08 & -0.88 & $\mathrm{X}$ \\
\hline 37 & 0.17 & 0.09 & 2.00 & $\mathrm{~V}$ \\
\hline 38 & 0.56 & 0.08 & 7.20 & $\mathrm{~V}$ \\
\hline 39 & 0.22 & 0.08 & 2.62 & $\mathrm{~V}$ \\
\hline 40 & 0.60 & 0.08 & 7.70 & $\mathrm{~V}$ \\
\hline
\end{tabular}




\begin{tabular}{|l|l|l|l|l|}
\hline No & Koefisien & Standar Error & Nilai t & Signifikan \\
\hline $4 \mathrm{I}$ & $0.4 \mathrm{I}$ & 0.08 & 4.98 & $\mathrm{~V}$ \\
42 & -0.12 & 0.08 & $-\mathrm{I} .48$ & $\mathrm{X}$ \\
43 & 0.35 & 0.08 & 4.24 & $\mathrm{~V}$ \\
& & & & \\
& & & & \\
\end{tabular}

Keterangan : tanda $\mathrm{V}=$ signifikan $(\mathrm{t}>\mathrm{I}, 96) ; \mathrm{X}=$ tidak signifikan

Dari tabel tersebut dapat dilihat koefisien muatan faktor dari item yang tidak signifikan sebanyak 6 item yaitu item nomor 3, 4, I2, I3, 36, dan 42 sedangkan sisanya signifikan. Berdasarkan pengujian tersebut, nampak bahwa terdapat koefisien muatan faktor yang bermuatan negatif. Dengan demikian item yang harus di drop dan tidak dapat dihitung skor faktornya yakni item nomor 3, 4, I2, I3, 36, dan 42. Artinya, bobot nilai pada item tersebut tidak akan diikutsertakan dalam analisis statistik uji hipotesis. Apabila skor faktor dari setiap item telah diperoleh maka skor tersebut yang akan dianalisis dalam uji hipotesis korelasi dan regresi.

\section{Penutup}

Hasil uji validitas konstruk terhadap instrumen Ryff's Psychological Well-Being Scale dengan menggunakan pendekatan confirmatory factor analysis mengungkapkan bahwa seluruh item bersifat unidimensional atau dengan kata lain hanya mengukur satu faktor saja, yaitu psychological well-being (selfacceptance, autonomy, positive relations with others, purpose in life, environmental mastery, dan personal growth). Dapat disimpulkan bahwa model satu faktor yang diteorikan oleh instrumen Ryffs Psychological Well-Being Scale ini dapat diterima. Hal ini dikarenakan seluruh item instrumen ini memenuhi kriteriakriteria sebagai item yang baik, yaitu; (I) memiliki muatan faktor positif, (2) valid (signifikan, t > I.96), dan (3) hanya memiliki korelasi antar kesalahan pengukuran item yang tidak lebih dari tiga atau dengan kata lain item tersebut bersifat unidimensional.

\section{Daftar Pustaka}

Huppert, Felicia A. (2009). Psychological well-being: evidence regarding its causes and consequences. Journal Compilation International Association of Applied Psychology, I (2), I37-I64, DOI:I0.IIII/j.I7580854.2009.01008.x.

Keyes, C L.,; Shmotkin, D; \& Ryff, C D. (2002). Optimizing well-being: the emprirical encounter of two tradition. Journal of Personality and Social Psychology, I007-1022.

Ryff, C. D. \& Keyes, C. L. M. (1995). The Structure of Psychological Well-Being Revisited. Journal of Personality and Social Psychology.

Ryff, Carol D. (1989). Happiness is everything, or is it? Explorations on the meaning of psychological wellbeing. Journal of Personality and Social Psychology.

Umar, J. (20I I). Bahan Ajar Psikometri.Tidak dipublikasikan.

Vazquez, C; Hervas, G; Rahona, J J, \& Gomez, Diego. (2005). Psychological well-being and health: contributions of positive psychology. Journal of Clinical and Health Psychology. 